\title{
Influence of plot size on distribution analyses and effects of altitude on spatial patterns of palm heart in Submontane Tropical Rainforest, Ibirama, Brazil
}

\author{
Influencia del tamaño de parcela en el análisis de la distribución y los efectos de la altitud \\ sobre los patrones espaciales de palmito en la selva tropical submontana, Ibirama, Brasil
}

\author{
Lílian Daniel Pereira ${ }^{\text {a*, }}$, Thomas Schröder a, Juliane Chies ${ }^{\text {b }}$, Flávio Zanchetti c, Frederico Dimas Fleig a \\ * Correspondent author: ${ }^{a}$ Universidade Federal de Santa Maria, Programa de Pós-Graduação em Engenharia Florestal, \\ Santa Maria, Brasil, tel.: 55-55-96339550, liliandapereira@yahoo.com.br \\ ${ }^{\mathrm{b}}$ Grupo CEEE, Porto Alegre, Brasil. \\ ${ }^{c}$ ICMBio/Instituto Chico Mendes de Conservação da Biodiversidade, Ibirama, Brasil.
}

\begin{abstract}
SUMMARY
The knowledge about the behavior of the species and its analysis is very important in order to support management and conservation techniques. Therefore, the aims of this study were to analyze spatial distribution of palm heart (Euterpe edulis) and verify the influence of altitude on spatial distribution. The spatial distribution was calculated with the indexes of Payandeh, Hazen and Morisita. To assess the influence of altitude on spatial distribution, we calculated Kolmogorov-Smirnov test of complete spatial randomness with altitude as covariate and we also calculated an estimate of the intensity as a function of altitude. The study was developed in a seed collection area in Floresta Nacional (FLONA) in Ibirama, Santa Catarina. Sampling consisted of five ten-meter-wide strips. False coordinates of E. edulis with more than $10 \mathrm{~cm}$ of diameter at breast height were recorded. Euterpe edulis showed spatial clustered distribution in all plot sizes and all indexes used. Morisita was the best index for describing spatial distribution. The occurrence of E. edulis was higher in intermediate altitude. Therefore, it is recommended to take into consideration the existence of clusters and of altitude influence in order to promote management and conservation of this species.
\end{abstract}

Key words: Payandeh index, Hazen index, Morisita index.

\section{RESUMEN}

El conocimiento acerca del comportamiento de las especies y de cómo analizarlo es muy importante para amparar las técnicas de manejo y conservación. De tal modo, el objetivo de este estudio fue analizar la distribución espacial del palmito (Euterpe edulis) y evaluar la influencia de la altitud en su distribución espacial. La distribución espacial fue calculada con los índices de Payandeh, Hazen y Morisita. Con el objetivo de evaluar la influencia de la altitud, fue empleada la prueba de Kolmogorov-Smirnov para la aleatoriedad espacial completa con la altitud como una covariable. También se estimó la intensidad como función de la altitud. El estudio se realizó en el área de recolección de semillas de la Floresta Nacional (FLONA) de Ibirama, Santa Catarina, Brasil. La muestra fue compuesta de cinco zonas de 10 metros de amplitud. Falsas coordenadas de E. edulis con más de $10 \mathrm{~cm}$ de diámetro a la altura del pecho fueran registradas. Euterpe edulis mostró distribución espacial reunida en todos los tamaños de las unidades utilizadas. El índice de Morisita fue aquel que mejor describió la distribución espacial. La ocurrencia de E. edulis fue superior en altitudes intermedias. Por lo tanto, se recomienda tener en cuenta los grupos y la influencia de la altitud para promover el manejo y la conservación de esta especie.

Palabras clave: índice de Payandeh, índice de Hazen, índice de Morisita.

\section{INTRODUCTION}

Spatial distribution of species consists of relevant information for ecological analyses because it helps to understand forest dynamics and formation. Spatial distribution depends on complex environmental and ecological factors (Capretz 2004). Biotic and abiotic conditions such as soil, water and light are factors that influence species spatial distribution (Silva et al. 2009).

The measurement of clustering and dispersion of a species is crucial to determine how the species uses re- sources and how it should be used as a resource (Condit et al. 2000). Therefore, a management and conservation plan for a species should be based on dispersion features (Austin 2002).

There are several methods to study spatial distribution. The most common methods to analyze spatial distribution are based on quadrats (Silva et al. 2009), however, the size of the sample can influence on this analysis (Zhang et al. 2013). Furthermore, technical features such as density and frequency are very helpful in understanding how tree species are distributed (Oosting 1956). In this context, it is 
important to assess how the size of the plot will influence on the results of spatial distribution in quadrat methods.

The palm heart (Euterpe edulis Mart.) is a key plant of tropical rainforests (Capretez 2004) and has a historical legacy in Brazil once it became commercially important. Its products are oil, fruit, heart, stipe (in constructions) and leaves (in several products) (Bondar 1964, Milanesi et al. 2013). It is known that spatial distribution of E. edulis is cluster (Anjos et al. 1998, Oliveira et al. 2001, Costa Silva et al. 2003), and that this species prefers areas rich in water content; however, there is no specifications regarding the relationship of this species with altitude. Therefore, this study aimed at analyzing the spatial distribution of E. edulis in different plot sizes, as well as at understanding the influence of altitude on spatial distribution.

\section{METHODS}

The study was carried out in a seed collection area in Floresta Nacional (FLONA) in Ibirama, a Federal Conservation Unit, located in the municipalities of Ibirama, Apiúna and Ascurra, in the region of Vale do Itajaí, Santa Catarina State, Brazil. The climate was classified as humid subtropical (Cfa) according to Köeppen climate class. Mean annual temperature variation is $17.0{ }^{\circ} \mathrm{C}$ to $19.1{ }^{\circ} \mathrm{C}$ with maximum monthly temperature ranging from $23.5^{\circ} \mathrm{C}$ to $26.0^{\circ} \mathrm{C}$ and minimum of $11.8^{\circ} \mathrm{C}$ to $15.4^{\circ} \mathrm{C}$. Total annual rainfall can vary from 1,320 $\mathrm{mm}$ to $1,640 \mathrm{~mm}$ (Ministério do Meio Ambiente 2008).

Soil was classified into red-yellow Acrisol, Cambisols and two types of Neossols. Relief was classified as mountainous. The native vegetation of the area was classified as Submontane Tropical Rainforest, in a stage of advanced regeneration. The area went through forest exploitation in the 1970s, when the species of highest commercial value were removed (Ministério do Meio Ambiente 2008).

Five ten-meter-wide strips towards magnetic north were installed. The strips were arranged in a parallel position distant $150 \mathrm{~m}$ one from the other. With total length of $250 \mathrm{~m}$ for strip 01, $200 \mathrm{~m}$ for strip 02, $225 \mathrm{~m}$ for strip 03, $250 \mathrm{~m}$ for strip 04 and $275 \mathrm{~m}$ for strip 05. Euterpe edulis palms within these strips with a diameter at breast height of more than $10 \mathrm{~cm}$ had their false geographical coordinates recorded and the size limit of diameter at breast height was correspondent to reproductive stage (Raupp et al. 2009). Data were collected from March to April 2008.

The different plot sizes were obtained by the subdivision of the strips in different lengths, with amplitude of five meters (from 05 to $125 \mathrm{~m}$ ), which resulted in twenty-five different plot sizes (figure 1), with total sampled area for each plot size being different, depending on length. For example, plots $5 \mathrm{~m}$ in length covered the total area of all strips; however, plots $10 \mathrm{~m}$ in length did not cover the total area, because strip 2 has $225 \mathrm{~m}$, hence $5 \mathrm{~m}$ remain without analysis.

In order to understand the spatial distribution, we calculated absolute density and frequency (Oosting 1956);

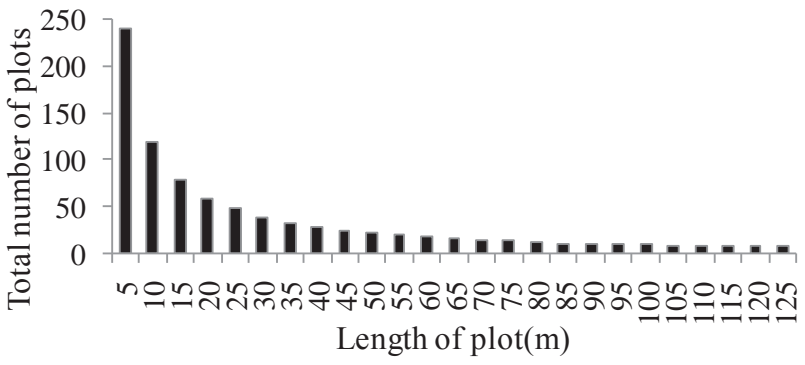

Figure 1. Different plot sizes, with length from 5 to $125 \mathrm{~m}$, and total number of plots.

Diferentes tamaños de unidades de muestreo, ancho 5-125 m, y número total de parcelas.

Payandeh index (Payandeh 1970); Hazen index (Hazen 1966); and Morisita index (Morisita 1959) and assessed by its stability in different plot sizes by coefficient of variation. The Payandeh index denotes cluster when the index value is higher than 1.5 , tending to cluster when index value is between 1.5 and 1 and random when index value is less than 1. Hazen index is analyzed by the chi-square test; if the value of the index is higher than the tabulated value for $99 \%$ probability, then the data are clustered (degree of freedom ranged from 239 for $5 \mathrm{~m}$ long plots until 8 for $125 \mathrm{~m}$ long plots) and the Morisita index is clustered when the value index is higher than 1, and it was tested by the chi-square test.

We obtained points of altitude with GPS and described the whole altitude profile through the polynomial regression analysis. To evaluate the altitude influence on E. edulis density we calculated Kolmogorov-Smirnov test of CSR (Complete Spatial Randomness) with altitude regression as covariate and we also calculated an estimate of the intensity as a function of altitude. The calculations were made with software R (R CORE TEAM 2013) and the package 'spatstat' (Baddeley and Turner 2005).

\section{RESULTS}

Absolute density ranged from 136.7 to 155.4 individuals per hectare, depending on plot size. The lowest density was observed in plots of 05 and $25 \mathrm{~m}$, and the highest occurred in plots of $115 \mathrm{~m}$ (this plot size was the smaller sampled area at $0.92 \mathrm{ha}$ ). The absolute frequency increased according to the increase in the size of the plots (figure 2).

The graphical representation of spatial distribution (figure 3) demonstrates areas with high and low concentration of E. edulis. The analysis of figure together with absolute density and frequency indicates that the species tends to cluster.

Spatial distribution of $E$. edulis was clustered based on Payandeh, Hazen (with $P<0.01$ ) and Morisita (with $P<$ 0.01 ) indices, in all plot sizes (table 1). Nevertheless, they 
were different in variation: the coefficient of variation was $37 \%$ for Payandeh, $75 \%$ for Hazen and $11 \%$ for Morisita index. For Morista and Hazen the index values decreased, and for Pyandeh the index values increased for larger plots, indicating that cluster was weaker, probably because the standard deviation increases for larger plots (figure 4).

The altitude of seed collection area in Floresta Nacional (FLONA) in Ibirama varied between 329 and $369 \mathrm{~m}$. The polynomial regression analysis represented the profile of altitude as well. Strip 01 has the lowest altitudes. This

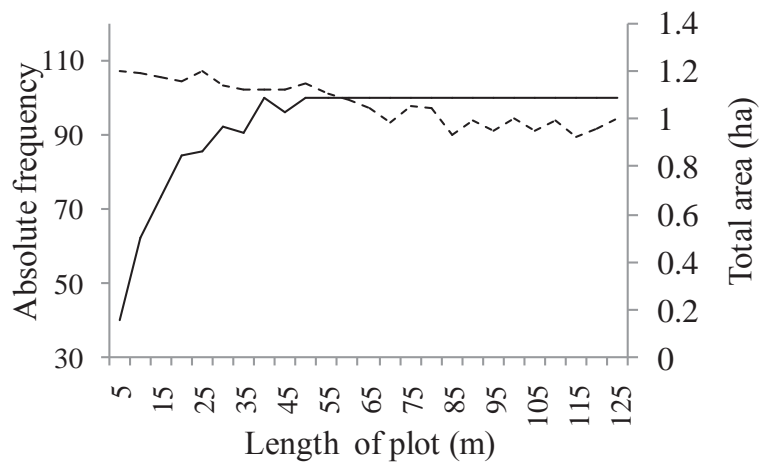

Figure 2. Absolute frequency (full line) of Euterpe edulis and total area (dotted line), based on plot size, length range from 5 to $125 \mathrm{~m}$ and width of $10 \mathrm{~m}$.

Frecuencia absoluta de Euterpe edulis basado en el tamaño de la unidad de muestro, con intervalo de longitudes de 05 a $125 \mathrm{~m}$ y la anchura de $10 \mathrm{~m}$.

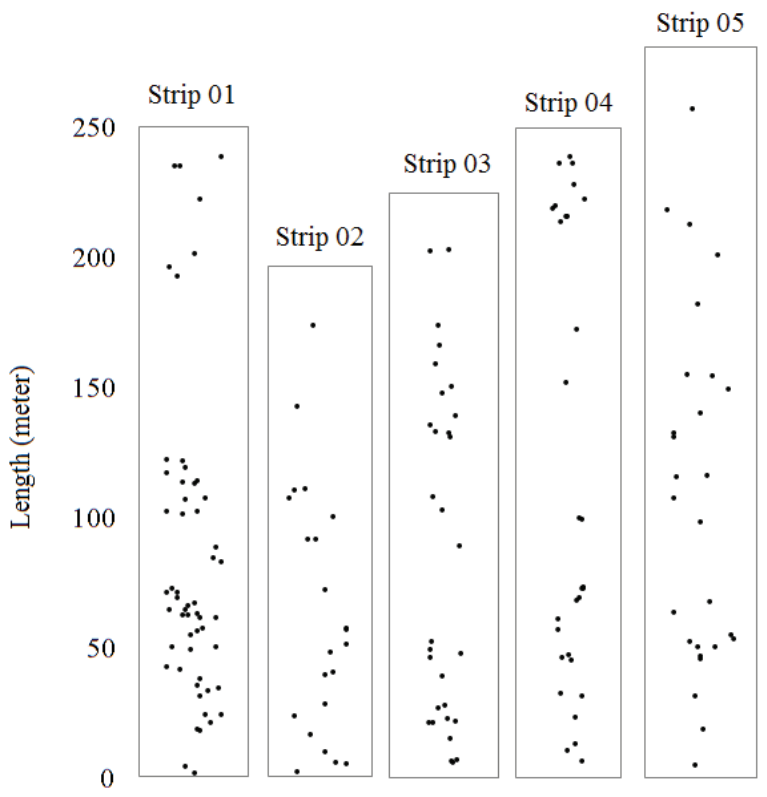

Figure 3. Distribution of Euterpe edulis in strips 01, 02, 03, 04 and 05 at FLONA in Ibirama.

Distribución de Euterpe edulis en las bandas 01, 02, 03, 04 y 05 en FLONA Ibirama. strip crosses a watercourse at length of $150 \mathrm{~m}$. The other strips have similar profile, tending to increase in altitude until one specific point, which is the peak, and then altitude decreases (figure 5).

The Kolmogorov-Smirnov test of CSR result indicated that altitude influenced the occurrence of $E$. edulis in strip $01(\mathrm{D}=0.2665, P<0.01)$, in strip $02(\mathrm{D}=0.3465$, $P<0.01)$, and strip 04 ( $\mathrm{D}=0.339, P<0.01)$, and no influence was observed in strip $03(\mathrm{D}=0.1734, P=0.2929)$ and strip $05(\mathrm{D}=0.2022, P=0.1912)$.

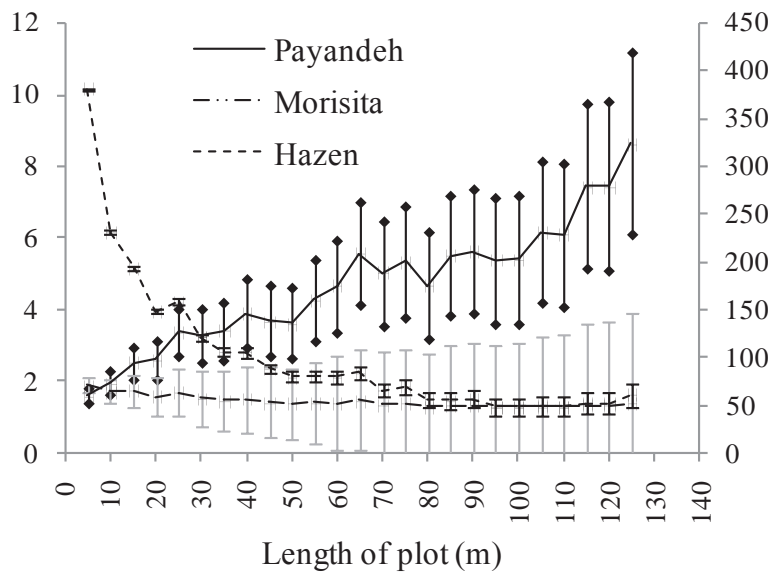

Figure 4. Plot size influence index scores with standard deviation bars.

Puntajes de índice de influencia del tamaño de parcela, con sus desviaciones estándar.
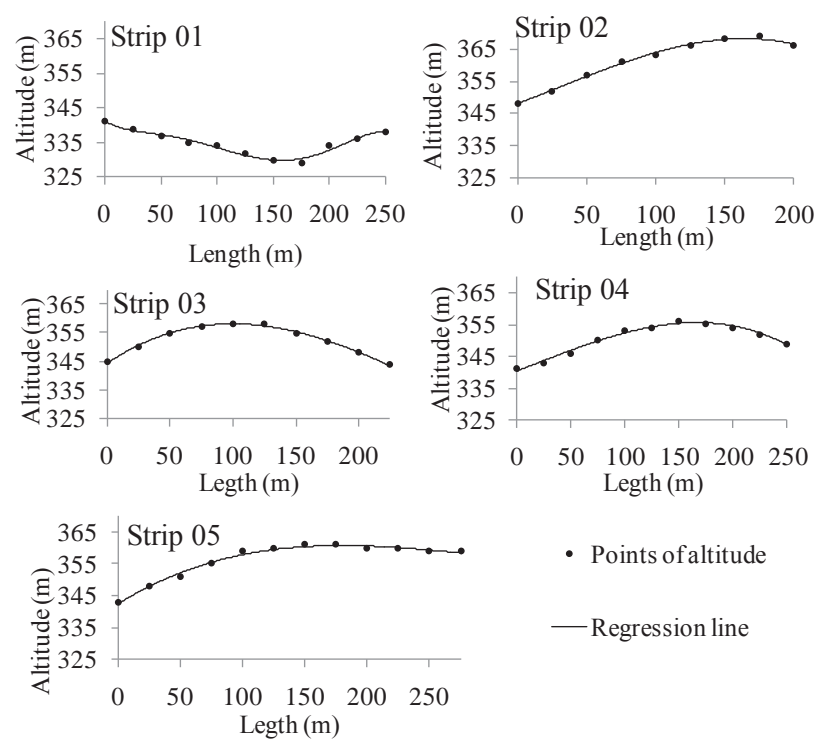

- Points of altitude

- Regression line

Figure 5. Profile altitude in strips $01,02,03,04$ and 05 at FLONA in Ibirama. Ibirama. 
Table 1. Payandeh, Hazen and Morisita indices for all plot sizes, with length from 5 to $125 \mathrm{~m}$. Índices Payandeh, Hazen y Morisita para todos los tamaños de las parcelas, ancho 5-125 m.

\begin{tabular}{|c|c|c|c|c|c|c|c|c|c|}
\hline \multirow{2}{*}{ Index } & \multicolumn{9}{|c|}{ Lenght of plot (m) } \\
\hline & 5 & 10 & 15 & 20 & 25 & 30 & 35 & 40 & 45 \\
\hline Payandeh & 1.59 & 1.96 & 2.51 & 2.60 & 3.36 & 3.26 & 3.39 & 3.89 & 3.68 \\
\hline Morisita & $1.87 *$ & $1.69 *$ & $1.72 *$ & $1.56 *$ & $1.68 *$ & $1.51 *$ & $1.46^{*}$ & $1.49 *$ & $1.41^{*}$ \\
\hline \multirow[t]{3}{*}{ Hazen } & $380.4 *$ & $230.7^{*}$ & 193.3* & $147.9 *$ & $158.0^{*}$ & $120.5^{*}$ & $105.1^{*}$ & $104.9 *$ & $88.4^{*}$ \\
\hline & \multicolumn{9}{|c|}{ Lenght of plot (m) } \\
\hline & 50 & 55 & 60 & 65 & 70 & 75 & 80 & 85 & \\
\hline Payandeh & 3.62 & 4.26 & 4.65 & 5.57 & 5.01 & 5.34 & 4.66 & 5.49 & \\
\hline Morisita & $1.36 *$ & $1.41^{*}$ & $1.39 *$ & $1.47^{*}$ & $1.36^{*}$ & $1.37 *$ & $1.28^{*}$ & $1.32 *$ & \\
\hline \multirow[t]{3}{*}{ Hazen } & $79.7 *$ & $80.9 *$ & $79.0 *$ & $83.5^{*}$ & $65.2^{*}$ & $69.5^{*}$ & $55.9 *$ & $54.9 *$ & \\
\hline & \multicolumn{9}{|c|}{ Lenght of plot (m) } \\
\hline & 90 & 95 & 100 & 105 & 110 & 115 & 120 & 125 & \\
\hline Payandeh & 5.63 & 5.37 & 5.39 & 6.14 & 6.09 & 7.42 & 7.44 & 8.64 & \\
\hline Morisita & $1.32 *$ & $1.28 *$ & $1.28 *$ & $1.29 *$ & $1.27 *$ & $1.32 *$ & $1.30 *$ & $1.36^{*}$ & \\
\hline Hazen & $56.3 *$ & $48.3^{*}$ & $48.5^{*}$ & $49.1^{*}$ & $48.7 *$ & $52.0 *$ & $52.1 *$ & $60.4^{*}$ & \\
\hline
\end{tabular}

Where: $* P<0.01$

The estimate of intensity as a function of terrain slope indicates that in strips 02 to 05 there is a tendency for the species to appear in big number at intermediate altitude from 340 to $350 \mathrm{~m}$, and the density decreases at higher altitude, on top. Strip 01 presented behavior different from that presented by the others and smaller density in lower altitude (figure 6).

\section{DISCUSSION}

The observed low density in plots with 05 and $25 \mathrm{~m}$ of length was caused by the enlargement of the sampled area without more inclusion of individuals of E. edulis. The density of E. edulis in tropical rainforests is highly variable (table 2). The density detected in this study was intermediate, however, the minimum diameter at breast height for most studies cited is five, and it should provide higher densities.

As the plot size enlarged the probability of E. edulis presence in each plot increased. The increase of a species frequency along with the enlargement of the plot size or the number of plots is always expected. Thus, in order to compare studies we must take into account the size and number of plots.

The frequency was similar to the one observed in other studies, $78 \%$ in plots of $10 \mathrm{~m} \times 20 \mathrm{~m}$ (Negrelle 2006) and $100 \%$ in plots of $10 \mathrm{~m} \times 90 \mathrm{~m}$ (Aguiar 2003).

All spatial distribution methods estimated cluster pattern, in all different sizes, despite the knowledge that cluster intensity declines with increasing spatial scale (Zhang et al. 2013). The Morisita index did not show variation among different plot sizes and was a consistent index for spatial distribution analyses. Payandeh index, despite its simplicity, proved to be as efficient as Morisita index. The cluster pattern may have occurred in all plot sizes due to high frequency and density of the species. This was reflected in the case of Payandeh index that was clustered in all sizes because the ratio between the variance and the average has remained nearly constant.

Euterpe edulis showed cluster and wide dispersion in ground. Other studies also show clustered spatial distribution of E. edulis (Anjos et al. 1998, Oliveira et al. 2001, Costa Silva et al. 2003). The seed-dispersion pattern of this species can explain its behavior (autochoric and zoochoric); zoochoric seed-distribution tends to properly distribute the species in ground, and autochoric seed-dispersion form distribution patterns clustered (Zhang et al. 2013), besides the fact that seedlings of $E$. edulis show preference for sites near to the mother plant (Bovi et al. 1990, Puerta-Piñero and Lázaro, 2013), and the highest probability of survival and growth of seedlings is higher at a distance of $4 \mathrm{~m}$ from the mother plant (Silva Matos and Watkinson 1998).

The lack of influence of altitude calculated by Kolmogorov-Smirnov test in strip 05 could be explained by the characteristics of altitude, which in this strip presented little variation. However it was not possible to explain what happened with strip 03 , because, even with the lack of influence of altitude for Kolmogorov-Smirnov test, the estimate of intensity as a function of terrain slope indicates behavior similar to that presented by other strips. 
Strip 01

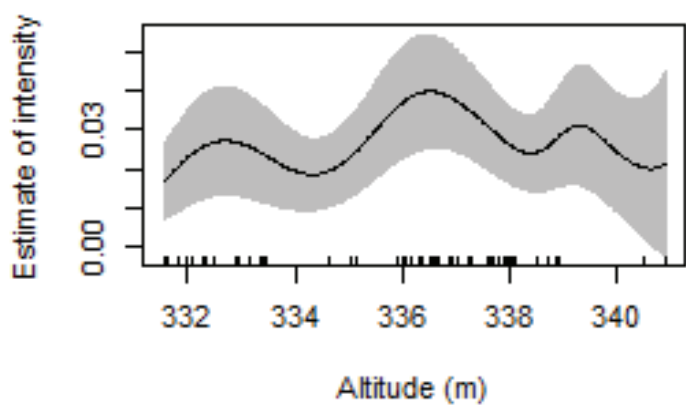

Strip 03

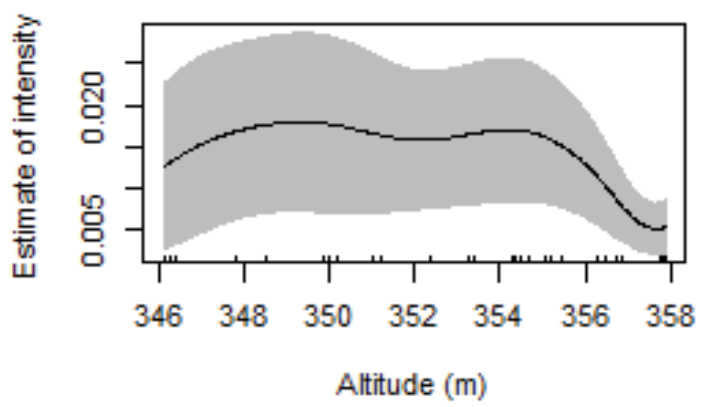

Strip 05

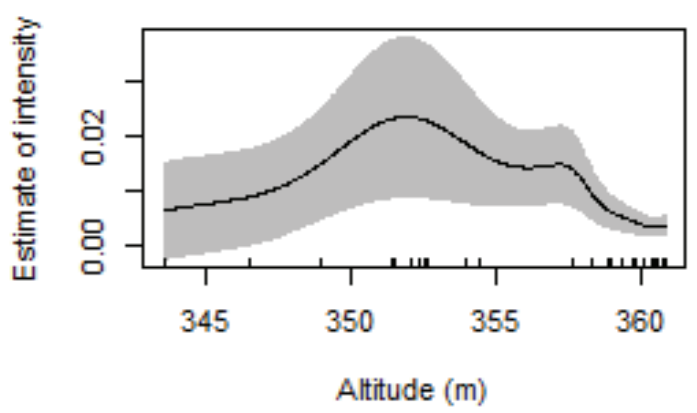

Strip 02

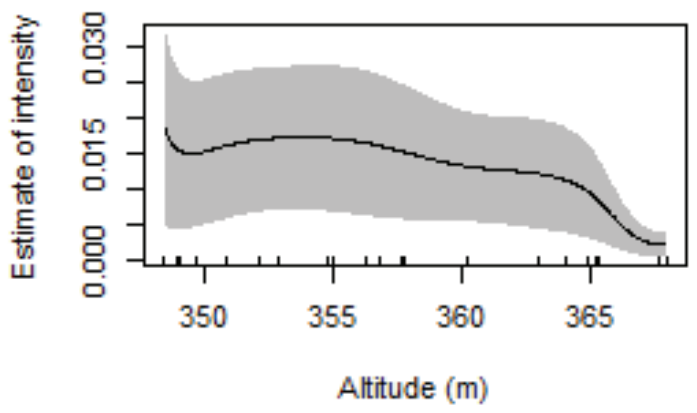

Strip 04

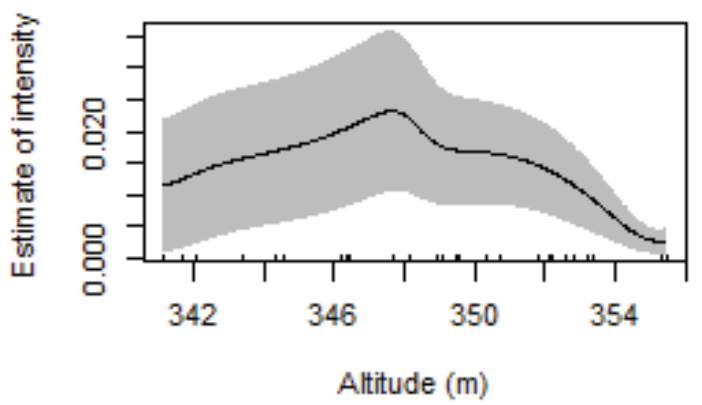

Figure 6. Estimate of intensity of Euterpe edulis (number per unit of area) as a function of altitude, for each strip and altitude profile. Estimación de la intensidad de Euterpe edulis como una función de la pendiente del terreno, para cada pista y perfil de la altitud.

Table 2. Density of Euterpe edulis in different studies of tropical rain forests.

Densidad de Euterpe edulis en diferentes estudios de la selva tropical submontana.

\begin{tabular}{cccc}
\hline Density (individuals/hectare) & Inclusion DBH $(\mathrm{cm})$ & Plot size $(\mathrm{m})$ & Citation \\
\hline 88 & 05 & $10 \times 20$ & Negrelle $(2006)$ \\
188,19 & 05 & $10 \times 90$ & Aguiar (2003) \\
730 (in 1999) and 759 (in 2001) & 05 & $10 \times 25$ & Ghoddosi (2005) \\
143 & 05 & $10 \times 10$ & Campos et al. (2011) \\
101 & 10 & $10 \times 10$ & Raupp et al. (2009) \\
\hline
\end{tabular}


The superior frequency of $E$. edulis in intermediate altitude could be associated with high intensity of catastrophic winds, which may cause tree fall and create conditions that favor the regeneration of E. edulis, with better growth in clearing areas (Nakazono et al. 2001). Although the species show association with higher soil moisture (Silva Matos and Alves 2008, Silva Matos and Watkinson 1998), the absence of species near a watercourse in strip 01 probably occurred because of higher canopy height, disfavoring regeneration of $E$. edulis, and not because of the watercourse itself. The low frequency of $E$. edulis in the top could have occurred due to the influence of rain. Silva Matos and Watkinson (1998) found that the rain carries most of dispersed seeds. Thus, the influence of altitude may reflect only the influence of physical factors such catastrophic winds, rain and biotic factors such as canopy height. Hence the occurrence of the species may not be directly influenced by altitude, although more studies investigating these relationships are needed.

The species E. edulis is on the Official List of the Brazilian Flora Endangered Species; therefore, its exploitation is forbidden. The Normative Instruction No. 6 of the Ministry of Environment, Article ${ }^{\text {th }}$, states that action plans should be developed so that any species considered endangered could be taken off the list. Thus, the management and conservation of this species should take into account the existence of these palm heart groups. If its logging is allowed in the future, it should respect the clustered spatial distribution and avoid logging an entire group, looking for the preservation of genetic population variability. Seed collection should also take into account the different clusters to maximize variability. The clustered spatial distribution facilitates collection of pulp fruit, the only form of exploration allowed for E. edulis.

The wide distribution of the species in the field and its clustered distribution pattern indicate a potential species for management, although its exploitation is prohibited. When analyzing a managed site, Raupp et al. (2009) observed a large amount of seedling and immature individuals, indicating the species potential to regenerate.

\section{CONCLUSIONS}

All indices used to describe spatial patterns demonstrate a clustered spatial distribution for Euterpe edulis; however, the Morisita index is the best for the analysis of spatial distribution because it is little influenced by plot size.

The management of this species should avoid eradication of cluster formations.

Moreover, the influence of altitude or physical and biotic factors should be considered for management. It is also necessary to observe the frequency of strong winds in the region because even if it favors the establishment of regeneration it is important to conduct management carefully avoiding further damage.

\section{ACKNOWLEDGMENTS}

We would like to thank CAPES - Coordination for the Improvement of Higher Education Personnel, which supported this study and Instituto Chico Mendes.

\section{REFERENCES}

Aguiar OT. 2003. Comparação entre os métodos de quadrantes e parcelas na caracterização da composição florística e fitossociológica de um trecho de Floresta Ombrófila Densa no Parque Estadual "Carlos Botelho" - São Miguel Arcanjo, São Paulo. Disertacíon Ingeniero Forestal. Piracicaba, Brasil. Escola superior de Agricultura "Luiz de Queiroz", Universidade de São Paulo. 119 p.

Anjos A, HTZ Couto, A Reis. 1998. Análise do efeito de um manejo em regime de rendimento sustentável sobre o padrão de distribuição espacial do palmiteiro (Euterpe edulis Martius), utilizando a função K de Ripley. Revista Árvore 22(2): 215-225.

Austin M. 2002. Spatial prediction of species distribution: an interface between ecological theory and statistical modelling. Ecological Modelling 157: 101-118.

Baddeley A, R Turnerm. 2005. Spatstat: An R Package for Analyzing Spatial Point Patterns. Journal of Statistical Software 12(6): 1-42.

Bondar G. 1964. Palmeiras do Brasil. São Paulo, Brasil. Instituto de Botânica. 159 p.

Bovi MLA, G Godoy Júnior, LA Sáes, EEM Mori. 1990. Subsídios para o sistema de manejo auto-sustentado do palmiteiro. Campinas, Brasil. Boletim Técnico 137. 25 p.

Campos MCR, JY Tamashiro, MA Assis, CA Joly. 2011. Florística e fitossociologia do componente arbóreo da transição Floresta Ombrófila Densa das Terras Baixas - Floresta Ombrófila Densa Submontana do Núcleo Picinguaba/PESM, Ubatuba, sudeste do Brasil. Biota Neotropica 11(2): 301312.

Capretz RL. 2004. Análise dos padrões espaciais de árvores em quatro formações florestais do estado de São Paulo, através de análises de segunda ordem, como a função k de Ripley. Disertacíon Ingeniero Forestal. Piracicaba, Brasil. Escola superior de Agricultura "Luiz de Queiroz”, Universidade de São Paulo. 93 p.

Condit R, SA Peter, P Baker, S Bunyavejchewin, S Gunatilleke, N Gunatilleke, SH Hubbell, RB Foster, A Itoh, JV LaFrankie, HS Lee, E Losos, N Manokaran, R Sukumar, T Yamakura. 2000. Spatial patterns in the distribution of tropical tree species. Science 288(5470): 1414-1418.

Costa Silva MGCP, AMV Carvalho, AMZ Martini, QR Araújo. 2003. Padrão espacial da palmeira juçara (Euterpe edulis MART.), na mata atlântica do sul da Bahia. Agrotrópica 15(2): 107-112.

Ghoddosi SM. 2005. Dinâmica do componente arbóreo (19992004) de um trecho de Floresta Ombrófila Densa em Blumenau, SC. Disertacíon Ingeniero Albiental. Blumenau, Brasil. Universidade Regional de Blumenau. 139 p.

Hazen WE. 1966. Analysis of spatial pattern in epiphytes. Ecology 47(4): 634-635.

Milanesi LDS, N Peroni, MS Reis. 2013. Use of the palm Euterpe edulis martius in landscape units managed by migrants of 
German origin in Southern Brazil. Journal of Ethnobiology and Ethnomedicine 9: 47. DOI: 10.1186/1746-4269-9-47

Ministério do Meio Ambiente. 2008. Plano de Manejo da FLONA de Ibirama, SC: Sumário executivo. Consulted 10 nov. 2010. Available in www4.icmbio.gov.br/flonaibirama/ download.php?id_download $=8$

Morisita M. 1959. Measuring of the dispersion of individuals and analysis of the distributional patterns. Memoirs of the Faculty of Science 2(21): 5-23.

Nakazono EM, MC Costa, K Futatsugi, MTS Paulilo. 2001. Crescimento inicial de Euterpe edulis Mart. em diferentes regimes de luz. Revista brasileira de Botânica 24(2): 173179. ISSN 1806-9959.

Negrelle RRB. 2006. Composição florística e estrutura vertical de um trecho de Floresta Ombrófila Densa de Planície Quaternária. Hoehnea 33(3): 261-289.

Oliveira RJ, W Mantovani, MMRF Melo. 2001. Estrutura do componente arbustivo-arbóreo da floresta atlântica de encosta, Peruíbe, SP. Acta Botânica Brasileira 15(3): 391-412.

Oosting HJ. 1956. The study of plant communities. San Francisco, USA. Freeman and Company. 389 p.

Payandeh B. 1970. Comparison of methods for assessing spatial distribution of trees. Forest Science 16(3): 312-317.

Puerta-Piñero C, Lázaro A. 2013. Análisis espacial en plántu- las de Euterpe edulis (Arecaceae) en el bosque Atlántico ¿Afecta la densidad de adultos a su distribución? Ecosistemas 22(3): 111-116. Doi: 10.7818/ECOS.2013.22-3.15

Raupp SV, P Brack, SLC LEITE. 2009. Aspectos demográficos de palmiteiro (Euterpe edulis Mart.) em uma área da Floresta Atlântica de Encosta, em Maquiné, Rio Grande do Sul. Iheringia 64(1): 57-61.

R Core Team. 2013. R: a language and environment for statistical computing. Vienna, Austria. R Foundation for Statistical Computing.

Silva KE, SV Martins, NT Santos, CAAS Ribeiro. 2009. Padrão espacial de espécies arbóreas tropicais. In Martins SV ed. Ecologia de Florestas Tropicais. Viçosa, Brasil. Universidad Federal de Viçosa. p. 217-244.

Silva Matos DM, AR Watkinson. 1998. The fecundity, seed and seedling ecology of Euterpe edulis Mart. (Palmae) in a fragment of semideciduous forest, Brazil. Biotropica 30: 595603.

Silva Matos DM, LF Alves. 2008. Palm species distribution and soil moisture in a swamp area of the atlantic forest, southeastern Brazil. Ecotropica 14: 69-74.

Zhang Z, G Hu, J Zhu, J Ni. 2013. Aggregated spatial distributions of species in a subtropical karst forest, southwestern China. Journal of Plant Ecology 6(2): 131-140. 
